\title{
Gözetim Toplumu Yönetimi ve Turizm Endüstrisi Açısından Değerlendirilmesi*
}

\section{Surveillance Society Management and the Evaluation of It in Terms of Tourism Industry}

\author{
Füsun İstanbullu Dinçer, ${ }^{a}$ Tolga Fahri Çakmak ${ }^{\text {b, ** }}$ \\ ${ }^{a}$ Prof. Dr., İstanbul Üniversitesi, İktisat Fakültesi, Turizm İşletmeciliği Bölümü, 34119, İstanbul/Türkiye. \\ ORCID: 0000-0001-9446-5519
}

b Öğr. Gör., Bartın Üniversitesi, Bartın Meslek Yüksek Okulu, Seyahat-Turizm ve Eğlence Hizmetleri Bölümü, 74100, Bartın/Türkiye. ORCID: 0000-0002-7952-1102

\section{MAKALE BILGİSİ}

\section{Makale Geçmişi:}

Başvuru tarihi: 18 Aralık 2017

Düzeltme tarihi: 26 Ocak 2018

Kabul tarihi: 06 Şubat 2018

\section{Anahtar Kelimeler:}

Gözetim Toplumu

Turizm

Yenilik

\section{A R T I C LE INFO}

\section{Article history:}

Received 18 December 2017

Received in revised form 26 January 2018

Accepted 06 February 2018

\section{Keywords:}

Surveillance Society

Tourism

Innovation

\section{ÖZ}

Turizm endüstrisi her geçen gün yenilik anlayışı doğrultusunda teknolojiye daha da entegre olarak, küresel otomasyon sistemleri aracıllğı ile turist hareketliliklerini bireysel boyuttan toplumsal boyuta farklı katmanlar halinde kayıt altına alarak turizm olayına katılanların izlenmesine daha şeffaf bir biçimde olanak sağlamaktadır. Bu durum gözetim toplumu olarak adlandırılan ve insanların izlenerek toplumsal güvenliğin sağlanması adı altında kısmen yönlendirilmesine de sebebiyet vermektedir. Öte yandan gözetim, turizm endüstrisi için bir sorun niteliği taşıyan müşterinin sadakatini sağlama hususunda önemli bir strateji unsuru olmaya da başlamıştır. Bu çalışmanın amacı gözetim toplumu kavramının turizm endüstrisinin geleceğinde nasıl bir role sahip olacağının, işletmelerin yönetimsel ilkeleri içerisinde nasıl yer edineceğinin analizini yapmaktır. Bu bağlamda ilgili alan literatürü taranmış ve kavramsal bir çerçevede konu ele alınmıştır.

\section{A B S T R A C T}

Every day, tourism industry provides monitoring of participants in tourism events in a transparent manner by integrating more technology; by recording as different layers to tourist mobility from individual to community; by global automation systems with innovative understanding. This situation called surveillance society gives rise to direct people partly for social security by monitoring of people. On the other hand, surveillance has started to be an important strategically element for creating customer loyalty being a problem for tourism industry. The purpose of this study is to analyse which role surveillance society will have in tourism future and make a place in administrative policies of managements. In this context, the literature on this field was scanned and the subject has been discussed in a conceptual framework.

\section{Giriș}

Sanayi toplumundan bilgi toplumuna geçiş ve küreselleşme sürecinin uluslararası düzlemde işletmelerden, bireylere tüm kademelere ulaşması, her sektör ve endüstride olduğu gibi hizmet sektörü ve turizm endüstrisi içinde uluslararası rekabeti çok daha yoğun yaşanır bir noktaya getirmiştir.

Birleşmiş Milletler Dünya Turizm Örgütü (BMDTÖ) 2016 y1lı verilerine göre, uluslararası turist sayısı 2015 yılına rakamlarına oranla \% 3.8 artarak 1.235 milyara ulaşırken
2017 yılı tahminlerinde, uluslararası turizmin, küresel ekonomi içinde \%3-\%4 büyüme göstereceği öngörülmektedir (UNWTO). 2030 yılı turizm öngörülerinde ise turist varışlarının 1,8 milyara ulaşacağı tahmin edilmektedir (UNWTO). Turizme katılımın giderek artacağ analiz sonuçları başta devletler olmak üzere uluslar ve uluslararası seyahat ve konaklama işletmelerini son derece ilgilendirmektedir. İşletmeler açısından konuyu ele aldığımızda talebin esneklik özelliği göstermediği turizm endüstrisinde gelecek eğilimlerin ve muhtemel turist

\footnotetext{
* Bu çalışma, 28-30 Mayıs 2015 tarihlerinde Konya'da I. Eurasia International Tourism Congress: Current Issues, Trends, and Indicators'da bildiri olarak sunulmuştur.

** Sorumlu yazar/Corresponding author.

e-posta: tolgafahricakmak@gmail.com
} 
istatistiklerini bilmek son derece önemlidir. Zira arz, bu bilgiler çerçevesinde oluşacaktır. Ülkeler açısındansa başta işletmelerin amaçladığı kar etme ve ekonomik yarar sağlama kaygısı kendini göstermekte, turizm yolu ile ülkenin döviz geliri arttırılması ve cari açı̆̆ın kapanmasına katkı ön plandadır. Fakat diğer yandan uluslararası güvenlik, kültürel mirasın korunması, artan nüfus ve turist aktiviteleri sebebi ile gelecek döneme ilişkin alınması gereken güvenlik önlemleri, taşıma kapasitesi bilgilerinin güncellenmesi ve sürdürülebilirliğin sağlanması ilkeleri önemli yer teşkil etmektedir.

Konuyu gözetim boyutunda ele aldığımıza ise öncelikli olarak gözetim ihtiyacının sebebi dikkat çekmektedir. Günümüz bilgi toplumu teknolojilerine dayalı piyasalarında rekabet en üst seviyede olup, bu da işletmeler için müşterilerin veya potansiyel müşterilerin istek ve beklentilerinin ne olduğu, gelecekte ne olacağı sorusu ve sorununu ortaya çıkartmaktadır. İşletmeler her ne kadar pazar araştırmaları yapıp tüketiciye ulaşmaya çalışsalar da, kimi zaman tam olarak tüketici isteklerine ulaşamamakta veya değişen talep yapısına uyum gösterememektedirler. $\mathrm{Bu}$ bağlamda sisteme uyum sağlamak bilgiden (enformasyon) geçmekte, bilgi ise günümüz teknolojileri ile çok daha geniş çaplı bir şekilde elde edilebilmektedir. Küreselleşme ile beraber teknolojiye dayalı gelişmeler bir yana gelişen teknolojilerin hayatın her alanına yayılmış olması ve dünyadaki çoğu bireye ulaşması, işletmelerin bilgi edinme isteği için önemli bir kaynak teşkil etmektedir. Çünkü günümüzde milyarlarca insan turizm ya da başka sebeplerle seyahat etmekte, kredi kartlar ile harcamalar yapmakta, uluslararası otomasyon sistemleri aracılığı ile rezervasyonlar, siparişler almakta ve vermektedir. Teknolojiye dayalı yapılan her işlemin kayıt altına alınması bireyler ile ilgili de bilgilerin depolanması anlamına gelmektedir. Milyonlarca insana ait depolanan milyarlarca veri ayıklanarak belirli kategorilere ayrılması, insanların yönelimlerini ortaya çıkarabildiği gibi onları yönetmek ve kontrol altında tutmak için bir yol haline gelmiştir. Öte yandan akıllı uygulamalar, sosyal medya faktörü, gps verileri insanları, takip etmeyi kolaylaştırdığı gibi bireyler arası örgütlenmeyi de daha mümkün kılmış bu da ulusal ve uluslararası çapta bir güvenlik zaafını oluşturmuştur. Zira gözetimin en önemli sebeplerinden biri suçlara engel olmak amacı ile izleme yapmaktır.

Gözetimin geldiği bir diğer nokta ise insanların gözetlenmekten haz alır hale gelmesidir. Özellikle sosyal medya platformları üzerinden gidilen yerler, yenilen yemekler, yapılan boş zaman aktiviteleri, davetler, toplantılar, iş görüşmeleri, şehir ülke gezileri ve gidilen bu yerlere dair yapılan yorumlar, bireylerce paylaşılmak sureti ile birer veri haline gelmektedir. Bu yolla büyük işletmeler ve devletler kitleleri nasıl izliyorsa bireylerde kimi davranışlarının izlenilmesinden ve bunun sosyal bir statü unsuru haline gelmesinden hoşnuttur. $\mathrm{Bu}$ durumu turizm endüstrisi açısından ele aldığımızda işletmeler açısından önemli bir firsat olarak değerlendirmek mümkündür. Hiç bir tanıtım maliyeti olmaksızın, işletmeye gelen müşterilerin hoşnut olduklarını belirten sosyal medya paylaşımları ve o paylaşımları izleyip gözetleyen diğer insanlar için soyut nitelikteki turistik ürün, olabildiğince somut bir yapıya bürünebilmektedir.
Bu çalışmada ilk olarak, günümüzde alanındaki akademik çalışmaların hızla arttığı ve teknoloji ile birlikte daha da hayatımızın içine giren gözetim kavramı ve gözetim toplumu mantığı turizm endüstrisi kapsamında ele alınmıştır. Bunun için öncelikle gözetim ve gözetim toplumu kavramları tarihsel süreç içerisindeki değişimleri ile açıklanarak günümüzdeki konumu üzerinde durulmuştur. Devamında teknolojik gelişmelerin ve yenilik akımının gözetime nasıl etki ettiğinin altı çizilerek turizm endüstrisinin yeniliğe verdiği önem ve turizm işletmelerinde ortan teknoloji, otomasyon kullanım alanları ile gözetim ilişkilendirilmiştir.

$\mathrm{Bu}$ çalışmanın amacı turizm endüstrisinin gözetim toplumuna olan katkısı ile gözetim toplumu mantığının turizm endüstrisine katkısının karşılaştırılarak işletmelerin yönetim kararları alma sürecinde teknoloji ve gözetimden nasıl yararlanacaklarının ve bu durumun etik yanın tartışılmasıdır.

\section{Gözetim ve Gözetim Toplumu}

Türk Dil Kurumu sözlüğünde gözetim, "gözetme işi, nezaret ve himaye" anlamlarına karşılık gelmektedir (TDK, 2017). Gözetim kelimesinin Fransızca kökenli bir kelime olduğunu vurgulayan Güven (2008) kelimenin ilk defa 18. yüzyılın son dönemlerinde bir kişinin hareketlerinin yakından izlenmesi anlamında kullanıldığını belirtmiştir. Aynı zamanda Concise Oxford sözlügünde ise gözetim, bir şüpheli veya suçlunun yakın takibi şeklinde açıklanmıştır.

Marx (2002) geçmiş dönemde gözetim kavramını açıklamak için yapılan tanımların günümüz gözetim kavramını tam olarak karşılamadığını savunmaktadır. Bu konuda özellikle Concise Oxford Sözlüğü örneğini veren Marx, ilgili tanımda vurgulanan şüphelilik durumunun günümüz gözetim paradigması ile tam olarak uyuşmadığının altını çizer. Ona göre günümüz gözetim mantığı ve bu alana hizmet eden teknolojiler şüphelilerin yakalanması merkezli olmayıp, genele uygulanan kategorili bir uygulamadır. Bireysel gözetim mantığından sıyrılmış bu anlayışta, örgütler, belirli zaman aralıkları, coğrafi sınırlar, sistemler ve insan kategorileri söz konusudur. Gözetim birey odaklı değil toplum odaklı bir şekilde sürer.

Özet olarak gözetim, kişisel verilerin elde edilmesi ve depolanması yoluyla polisiye, ticari, istihdam, yönetim gibi farklı alanlarda ve kurumlarda, sürekli genişleyen bir derinliği ifade edip, elde edilen verilerin analiz ve sentezlere tabi tutulmasıyla gündelik yaşamın her anını kendisine hedef olarak seçer (Güven, 2008: 64-67).

Giddens (1985) gözetimi toplumsal boyutta ele alarak bu kavramı gözetim toplumu kapsamında birbiri ile ilişkilendirilmiş iki görünüm olarak tanımlar. İlki veri toplama ilkesi esasına dayanan gözetim türüdür. Burada bir kurum, topluluk veya iktidarın saklamak isteyeceği kodlanmış bilgiler mevcuttur ve sadece biriktirme değil depolama da söz konusudur. Bireylere dair depolanan ve şifrelenen bu bilgiler, bireylerin eylemlerini yönetmek veya yön vermek için kullanılır. İkincisi denetleyici konumdaki gözetimdir. Bir topluluğun içerisindeki kimi bireylerin eylemlerinin, bu eylemler üzerinde otorite kuran k1sımca gözlenmesini içerir. Bu da gözetleyeni gözetlenen karşısında bir basamak yukarı taşır ki bunun da bir sonucu olarak gözetleyen gözetlenenin etkinlikleri üzerinde daha etkin bir kontrol sağlar. 
Westin ise bireylere ve topluma yönelik gözetimi kendi içerisinde üç başlık altında incelemiştir (Ketizmen, 2008: 193-194):

(i) Fiziksel Gözetim: Bireylerin rızası dışında bulundukları yerin takibi, yaptıkları konuşmaların dinlenmesi ya da yazışmalarına ulaşılması şeklinde gerçekleşen gözetimdir.

(ii) Psikolojik Gözetim: Bireylerin isteyerek vermediği kişisel bilgileri, çeşitli testler, anketler ve stratejiler ile elde edip gerekli enformasyonun sağlanmasıdır.

(iii) Veri Gözetimi: Literatürde "dataveillence" olarak da geçen terim bireylere veya toplumlara dair ağırlıklı olarak teknolojik yollarla depolanan verilerin toplanarak enformasyona dönüştürülmesi ve daha büyük çaplı gözetimin sağlanması yoludur.

Gözetim ve gözetim toplumu kavramları yeni birer faaliyet olmayıp toplumların gözetlenmesi ilkesi insanlığın ilk dönemlerinden beri varlığını sürdürmektedir. Eski çağlardan beri insanlar bir yandan yaptıklarını kontrol etmek diğer yandan başladıkları noktadan ne kadar ileri gidebildiklerini görme arzusu taşımışlardır. Ayrıca toplumsal açıdan gerekli yönetimi ve örgütlenmeyi sağlamak amacı ile kimi zaman kendilerini kimi zaman başkalarını gözlemlemişler ve davranışlarını da bu eksen çerçevesinde oluşturmuşlardır. Bauman (1987) devletlerin toplum ve bireyler üzerindeki gözetim fonksiyonunun modernizmin erken dönemlerine doğru kendini gösterdiğinden bahseder. Modern öncesi yaşamın cemaat merkezli toplumlarında bireylerin güvenliğini sağlama hususunda devlet tarafindan sağlanan net bir güvence olmaması ve tüm sınırlarını oluşturan coğrafyaya güvenlik açısından ulaşamaması, insanları kendi güvenliklerini sağlama mecburiyetinde bırakmıştır. $\mathrm{Bu}$ durumda bireylerin en büyük silahının birbirleri ile olan ilişkisi yani sosyallikleri olarak kendisini göstermiştir. Bir köy veya kasabanın sakinleri bu yakın ilişkilerden doğan sosyallikle birbirlerini tanımakta dolayısı ile gerekli güven ortamını sağlamaktaydılar. $\mathrm{Bu}$ şekildeki küçük yerleşim birimlerindeki şeffaflık ise alan içerisindeki gözetim unsurunu oluşturmaktadır. Bu gözetimde sadece birbirini tanıyan insanların şeffaflığı söz konusudur. Diğer yandan bu faaliyet yapısının tarihsel sürecini Dolgun (2008) üç başlık altında şu şekilde incelemektedir:

(i) İlk evre, ilkel topluluklardan modern çağa kadarki geniş zaman aralığını kapsamakta olup göçebe toplumları, feodal beylikleri, imparatorlukları içine almakta ve pastoral dönem olarak adlandırılmaktadır. $\mathrm{Bu}$ çağlardaki gözetimin temel amacı tarıma dayalı iş gücü denetimi, vergi kontrolü sağlanması ve savaş dönemlerinde eldeki potansiyel asker sayısını belirlemek olup nüfus sayımlarına dayanan bir gözetim olarak karşımıza çıkar.

(ii) İkinci evre ulus devletlerinin ortaya çıkması ve teknolojik gelişmeler ile birlikte teknik gözetim olarak adlandırılan evredir. $\mathrm{Bu}$ evrede ulus devletlerinin yönetici iktidarları bir yandan iktidarını sağlamlaştırmak ve toplumsal denetimi sağlamak diğer yandan devletin iç de diş tehditlere karşı korunması güdüsü ile hareket etmiştir. Bu bağlamda askeri örgütlenmeler, yoğun sanayileşme ve kapitalist işletme sayısı artmıştır. $\mathrm{Bu}$ gözetim türünün karakteristik özelliğini kamusal alanda bürokrasi, üretim alanında ise bilimsel yönetim ilkeleri oluşturmaktadir.

(iii) Üçüncü evre ise günümüz toplumsal yapısını, bireyselden kitlesele gündelik yaşamı gözetlemeye dayalı enformatik gözetim türüdür. Enformasyon teknolojilerinin gelişmelerine paralel olarak ortaya çıkan bu gözetim evresi yönetim kademesine çok daha geniş çaplı bir bilgi sunarak kişisel telefonlar, bilgisayarlar, internet ve uydu teknolojileri kaynaklarından beslenir. Devletler ya da büyük firmalar kurdukları ağlar ile insanların yaşamlarını daha ayrıntılı bir şekilde gözetleme şansına sahiptir. Bireylerin teknolojiye sahip olmasının kolaylaşması gözetlenmelerini de kolaylaştırmakta ve kapsamını genişletmektedir.

Nihayetinde günümüzde gelinen nokta bireylerin izlenmesini son derece kolaylaştırmış ve kapsamını arttırmıştır. Toplanan bilgilerin nitelik ve niceliği artmıştır. $\mathrm{Bu}$ artışın ve kolay bilgi sağlamanın temelinde de teknoloji ve yenilik büyük önem taşımaktadır.

\section{Gözetim Toplumunun Teknoloji ve Yenilik İlişkisi}

Lyon'a göre (2002) iletişim ve bilgi teknolojilerindeki değişim başta sosyal yaşantımızı ve ticaret mantığımızı değiştirmiş teknoloji bir yandan insanlığa hizmet ederken diğer yandan sosyo-kültürel yapıda ve gündelik yaşamda ciddi değişimlere sebep olmuştur. Artık iletişimde, insanlar arasında vücut dili aracılığı ile gerçekleşen davranışlar, insan ve makineler ya da otomasyon sistemleri aracılığı ile gerçekleşmeye başlamıştır. Dolgun (2004) ise bu süreci, insanın yönlendirici gücünün giderek teknolojinin arkasında kalmasına bağlamaktadır. Dolguna göre sanayi devrimi insanın kas gücünün ikamesinin ilk adımlarıdır. Bu süreçte ilk olarak buharlı teknolojilerin gelişmesi ile beraber teknoloji üretime aktif bir şekilde dâhil edilse de yine kas gücü yönlendirmesi ile hareket etmiştir. Buna verilecek en basit örnek ise seri araba üretimine geçiş aşamasında Ford firması ve onun geliştirdiği fordist anlayışta teknoloji ne kadar üretime katılmış olsa da aracın bütün cıvatalarını sıkmak yine kas gücü merkezli işlemiş, üretimde teknoloji henüz insanın yerine tam olarak geçememiştir (Roney, 2002). Ancak 1980'lerde bilgisayar teknolojisinin yaygınlaşması bu durumu kökten değiştirmiş, gelişmiş otomasyon sistemleri kas gücünün yerini giderek daha fazla almaya başlamıştır. Bu güç değişimi neticesinde teknoloji kas gücünü yönlendirir bir yapıya kavuşmuştur. Yönlendirme gözetim ve denetimi de beraberinde getirmiştir (Dolgun, 2004).

Gözetim her ne kadar tarihin çok eski çağlarından bu yana temel anlamda varlığını sürdürmüş olsa da, bilgi toplumu süreci ve iletişim teknolojilerindeki gelişmeler ile hayatı yönlendiren güç, kas gücünden bilgi teknolojilerine kaymıştır. Böylece, bir yandan gözetim alanı genişlerken, diğer yandan gözetimin derinliğini de artmış, gözetim için kullanılan yöntem ve materyallerde bu kapsamda değişmiştir. Klasik gözetim teknolojik gelişmeler ile yeni gözetime dönüşmüştür (Lyon, 2002: 50; Mattelart, 2012: 181).

Miller, gelişen teknoloji ile beraber hayatın her alanına uzanabilen konumdaki bilişim ve internet teknolojilerinin 
kullanımının kişisel verilerin gözetimi açısından eski dönemlere göre pek çok zorluğu ortadan kaldırdığını savunmaktadır. İnternet kullanımı öncesi yaşanan gözetim sıkıntılarını yazar şu dört başlık altında ele almıştır (Ketizmen, 2008: 193-194):

(i) Bireylere dair toplanan bilginin geleneksel olarak toplanması ve sınırlı kayıt imkânı ile üçüncü kişiler tarafından elde edilmesinin zorluğu,

(ii) Bireylere dair var olan bilginin sistematik olarak depolanmaması, bir merkezinin olmaması, derinlik açısından yüzeysel nitelikte olması ve her an erişim şansının mümkün olmaması,

(iii) Toplumun devingen yapısının takibi zorlaştırması,

(iv) İstatistik gibi alanların gelişmemesi sebebi ile var olan bilgilerin analiz ve yorumlanmalarında eksik kalınması.

Yukarıdaki bilgilerden hareketle günümüzde bilişim teknolojileri aracılığı ile daha önceki dönemlerde bilgi toplanması ve gözetim hususunda engel teşkil eden pek çok sorun çözülmüştür. Artık bilgiler sınırsız bir şekilde kayba uğramaksızın tam veri halinde kayıt edilebilirken, yapılan kategorilere ayırma amaca göre istenilen bilgiye ulaşımı daha da kolaylaştırmıştır. Bununla beraber ayrıntılı bilgi kaydı ve bu bilgiye istenildiği zaman istenildiği şekilde ulaşılması oldukça önemlidir. İstatistik alanında gelişmeler ve bu alanında teknoloji ile birleşerek SPSS gibi veri analiz programlarının yaygınlaşması toplanılan bilgilerin analizini çok daha kesin sonuçlara indirgemiş hata payını giderek düşürmüştür. Bu da eldeki verilerin sadece günümüzde ifade ettiği anlamın okunmasından ziyade gelecekte alacağı şekle dair güçlü yorumların yapılabilmesine de olanak sağlamıştır.

\section{Turizm Endüstrisinde Teknoloji Kullanımı ve Yenilik}

Günümüz küreselleşen dünyasında, bilgiye en hızlı ulaşabilen onu işleyebilen, yönetim çıktılarına ve faaliyetlerine dönüştürebilen işletmeler varlıklarını devam ettirebilmekte ve yoğun rekabet ortamında rakip işletmelerin önüne geçebilme firsatını ele geçirebilmektedir (Ahipaşaoğlu ve Kaya, 2005: 1).

Akademik literatürü incelediğimizde, turizm endüstrisini genel yapısı gereği insan odaklı bir endüstri olarak tanımlandığını görmekteyiz (Goeldner ve Ritchie 2009: 13; Walker ve Walker, 2011: 501). Fakat bu düşünce günümüzde giderek değişmeye başlayarak, ulaştırma işletmelerinden konaklama işletmelerine hizmette teknolojiye doğru hızlı bir yönelim olmuştur.

$\mathrm{Bu}$ gelişmeler öncelikli ve büyük ölçekli bir şekilde havayolu işletmeleri aracılığı ile ulaştırma işletmelerinde yaşandığını söylemek yanlış olmayacaktır. İletişimin son derece önemli olduğu ve uluslararası hareketlerin odak noktasındaki havayolları, küresel dağıtım sistemleri aracılığı ile turizm endüstrisine teknolojik gelişmeyi doğrudan sağlamış konumdadır (Mühim, 2012: 64-65). Devam eden süreçte internet faktörü karşımıza çıkmakta, başta seyahat acentalarının görevini üstelenen Expedia, Tripadvisor, Hotels, Booking gibi siteler paket turlardan, otel odası satışına pek çok görevi üstlenerek acentaların görevlerini yerine getirmeye başlamıştır. Teknolojiler bir yandan kimi gelir kalemlerini tehdit ederken bir yandan da yeni firsatlar sunmaktadır. Sanal gerçekçilik teknolojisi de bu fursatlardan biri olarak değerlendirilebilmektedir. Sanal gerçekçilik uygulaması turistik ürüne farklı bir boyut katarak soyut olarak algılanan ürünün doğasını somutlaştırmaya yakın bir konuma getirmektedir. $\mathrm{Bu}$ yeni teknolojiyi dünyanın en büyük tur operatörlerinden biri olan Thomas Cook, İngiltere, Almanya ve Belçika'daki merkezlerinde "Try Before You Fly" sloganı ile tatile başlamadan varılacak bölgeyi tanıma, görme şansı olarak sunmaktadır (VISUALISE, 2015).

Rehberlik mesleği de teknoloji ve yenilikten nasibini almaktadır. Gelişmiş gps destekli harita uygulamaları, müzeler ve sit alanlarına dair ayrıntılı yazılı ve sesli anlatımlar sunan uygulamalar turistlere artık ilk defa gittikleri destinasyonlarda bile isteğe göre rehber olmaksızın gezme alternatifi sunabilmektedir.

Otel işletmeleri açısından konuyu ele aldığımızda ise otellerde kullanılmaya başlanan yoğun teknolojik yatırımların uluslararası medya gündemine girecek kadar büyük çapta olduğu gözlenmektedir. Amerika'da Silikon Vadisi'nde bulunan bir otel, oda servis elemanı olarak robotları kullanmaya başlamış (Nytimes, 2014) öte yandan Japonya da 2016 senesinde açılan olan bir otel, personelinin \%90'ınını robot teknolojisinden yararlanarak işletmeye başlamış, resepsiyonda görüntü olarak insana benzeyen robotlar hizmet vermeye başlamıştır (Busines Insider, 2017).

Yukarıda bilgilerden hareketle genel olarak günümüz turizm endüstrisinde, teknolojinin geçmiş döneme göre çok daha aktif bir şekilde alt sektörlerde yer edindiği sonucuna varılmaktadır. Artık tüketiciler evlerinden çıkmadan ya da kısa süreli tatil zamanlarının tümünü harcamadan tatil yapacakları sayısız destinasyonu internet vasitasıyla inceleyebildiği gibi, ulaşım, konaklama ve tur paketlerini oturdukları yerden güvenli ve kısa süreli bir şekilde satın alabilir konuma gelmişlerdir. Konaklama sektöründeki son gelişmeler ise insan faktörünün giderek azalmaya başladığı bir sürece girilmesinin ilk adımlarını teşkil etmekte insan gücü yerini her gün daha fazla robot teknolojisine birakmaktadır.

\section{Turizm Endüstrisinde Gözetim Toplumu Yönetimi}

Turizm endüstrisi açısından gözetimi ele aldığımızda, gözetim faktörü hem güvenlik ve koruma gibi hizmetler sağlama hem de elde edilen verilerin analizi ile birlikte bir tür pazarlama unsuru olarak karşımıza çıkmaktadır. Hizmet unsurunun geçmişi günümüzden çok daha eski dönemlere kadar uzanmaktayken gözetimin pazarlama yönü teknolojik gelişmeler ile paralel bir gelişim göstermektedir.

Tarihin her aşamasında seyyahlar ile tüccarların, seyahat ve konaklamalarının gerek güvenlik gerek ticari sebepler ile devletlerce gözlendiği bilinmektedir. Antik devletlerde özellikle ticaret yolları devamlı gözetlenen ve devlet himayesinde bulunan topraklar olarak karşımıza çıkar. Anadolu'da Asur Ticaret Kolonileri çağında Asur topraklarından ticaret amacı ile gelen tüccarların ve gezginlerin güvenliklerinden Anadolu beyleri sorumluydu. Bölgesel hükümdarlar tüccarların mallarına ve kervanlarına yapılan saldırılardan oluşacak zararı ödemekle mükelleftiler. Buna benzer bir sistemi yine Anadolu Selçuklu Devleti döneminin konaklama tesisleri olan kervansaraylarda da 
görmekteyiz (Ahipaşaoğlu ve Değirmencioğlu, 2010: 108, 344). Bahsi geçen bu hizmet kapsamında yolların sürekli gözlenmesi ile yönetici iktidarın sorumluluğu üzerine alması, gözetimi güvenlik sınırları içerisinde tutmaktadır.

Kitle iletişim araçlarının etkinliğinin artışı, iletişim teknolojilerindeki hızlı ilerleyiş ve basın yayın teknolojilerinin gelişmesine ek olarak ülkeler arası ticari anlaşmaların yoğunlaşmasıyla yeni birliklerin kurulması bir yandan küreselleşmenin hızını arttırırken diğer yandan 21 . yüzyılın bilgi toplumu olarak değerlendirilmesi açısından önem taşımaktadır (İstanbullu Dinçer, 1999: 21). Tüm bu yoğun teknolojik gelişim ise bu gün turizm endüstrisi içerisinde de kendisini yoğun bir şekilde hissettirmektedir.

Turizm endüstrisindeki yoğun teknolojik yatırıma dayalı gelişmeler, doğal olarak gözetim kavramının turizm endüstrisi içerisinde giderek daha geniş bir yer tutmasına ve aktif bir şekilde varlığını hissettirmesine sebep olmaktadır. Pazarlama noktasında da önemli imkânlar sunmaktadır. Turistik işletmelerde konaklayan turistler günümüzde işletmeler açısından dev bir bilgi kaynağını da ifade etmektedir. Merkezi New York'ta bulunan otel franchisorı ve seyahat endüstrisinde hizmet sağlayıcı firma konumundaki Cendant kuruluşunun sadece 2000 yılında müşterilerinden topladığı veri bilgi miktarı 62 milyon rakamına ulaşırken; 2004 yılında Hilton Oteller zinciri otomasyon programı olan On Q aracılığı ile kendi müşterilerine ait 7,5 milyon veri kaydı girmiştir (Weaver, 2008: 9-10). Bu şirketlerin ilerleyen dönemlerindeki veri arşivlerinin boyutu bilinmemektedir.

Oteller sadece kendi otomasyon sistemleri aracılığı ile bu bilgi deposunu elde etmek yerine pazar araştırma şirketleri verilerinden de yararlanabilmektedir. Merkezi Denver, Colarado da bulunan bir başka pazar araştırma şirketi otellerden elde ettiği müşteri bilgilerinden hareketle 40 milyon isim ve ev adresinden oluşan devasa nitelikte bir bilgi havuzu oluşturmuştur. Havuz da müşteri tipleri, kaldıkları oteller, geceleme sayıları ve yaptıkları harcamalara göre farklı niş grupları oluşturarak oteller için önemli bir bilgi kaynağı da sağlamıştır (Weaver, 2008: 12).

Teknolojik açıdan yeniliğin hızlı bir şekilde etkilenmeye başladığ 1 ve gelecek dönemler içerisinde de bu ivmenin giderek hız kazanacağı görüntüsü bir yandan endüstri yapısında değişiklikler oluşturacağı gibi diğer yandan turistlerin gözetlenmesini de daha fazla mümkün kılacaktır. Çünkü teknolojiye dayalı her türlü sanal ve elektronik faaliyet ilgili teknolojik birimlerce kayıt altına da alınmaktadır. Bu kapsamda Tribe (2011) gözetim toplumunu turizm paradokslarından biri olarak ele aldığ çalışmasında, turizm etkinliklerinin gerçekleştirildiği ortamların büyük çoğunluğunun devlet ve özel işletmelerce gözetim altında olduğunu bildirerek bu gözetim dinamiklerini aşağıdaki gibi sıralamıştır:

(i) Mağazalar, havaalanları, demiryolları, plajlar, oteller vb. alanların izlenmesi için yaygın şekilde kullanılan kapalı devre televizyon sistemleri (CCTV) ve kameralar1

(ii) Hükümetler arası veri paylaşımı: Yaşanılan ülkeden, gidilecek ülkeye hükümetler arası pasaport, banka hesap vb. paylaşımları, (iii) Harcama kalıpları ile ilgili verilerin toplanması, kullanılması ve satışı: Amazon gibi internet satışı yapan firmalardan veri satın alımı, hediye kartları veya sık uçan yolcu bilgileri gibi,

(iv) Kimlik ve banka dolandırıcılıkları amacıyla yapılan veri taramaları,

(v) Sosyal ağ siteleri gibi paylaşım sitelerinden verilerin toplanmasi.

Gözetim dinamiklerinin bu şekilde turizm endüstrisi içerisinde yer bulması ise gözetimin etkilerinin ne olacağı, bu büyük veri toplama süreçlerinden korunmamız gerekip gerekmediği gibi soruları da beraberinde getirmektedir.

Prashyanusorn vd. (2009) ise yaptıkları çalışmada turizmde gözetimin yararlarına odaklanarak, geniş gözetim ağının sürdürülebilir turizme olan katkısı ve destinasyonlarda güveni sağlama yararının üzerinde durmuşlardır. Çalışmada turistlerin ziyaret ettikleri bölgede yabancı olduklarının anlaşılmasının kolay olmasının yan kesicilik, hırsızlık gibi olaylara davet çıkardığı ve gözetim sistemlerinin başta bu suç etkisini düşürmekte olduğu, devamlı gözetimle güvenlik güçlerinin suça anında müdahale şanslarının olduğu altı çizilmiştir. Gerçekten de literatürde yer alan farklı çalışmalarda da bir bölgede gelişen turizm hareketlerinin suç unsurlarını ciddi manada arttırdığını ortaya koymaktadır (Fujii ve Mak, 1980; Ryan, 1993; Holcomb ve Pizam, 2006). Prashyanusorn vd. (2009), gelecekte teknolojik gelişmeler ile gözetleme teknolojilerinin daha da fazla gelişerek, suç unsuru oluşturabilecek davranıştaki kişilerin doğrudan tespiti ve güvenlik hizmetlerine haber verilmesi şeklinde daha güvenilir destinasyonların yaratılmasının mümkün olduğu belirtilmiştir. Öte yandan gözetim, sadece turist güvenliği değil aynı zamanda kültürel miras niteliğindeki eserlerin zarar görmesine veya çalınmasına karşı da önemli bir koruma niteliği taşımaktadır.

Yukarıda yer verilen akademik yayınlarda yapılan yargılardan, sosyal paylaşım siteleri, internet ortamı ve turistik işletmelerde yapılan gözlemlerden hareket ile gözetim çeşitlerinin turizm endüstrisi açısından elde edilişi, artıları ve eksileri Westin'in (1970) gözetim toplumu kategorilerine göre uyarlanarak Tablo 1'de yorumlanmıştır.

Tablo 1 incelendiğinde öncelikli olarak gözetim türlerin turizm endüstrisinden nasıl çıktı sağladığı ve hangi bilgilere ulaşabildiği görülmektedir. Üç gözetim türünde de özel hayatın hiçe sayılarak ve bireyin onayı alınmaksızın hakkında verilerin tutulması esasından hareketle etik olmayan bir durum olduğu düşünülebilir. Bununla beraber potansiyel bir suç mahalli de olabilecek turistik bölgenin güvenliğinin gözetim dinamikleri ile sağlanıyor olması bir paradoks olarak karşımıza çıkmaktadır. Teknoloji yatırımının giderek arttığı düşünüldüğünde gözetim unsurunun da turistik işletmelerde çok daha kapsamlı bir hal alınacağı çıkarımı yapılabilinir. Turistik hizmeti satın alma sürecinden hizmetin üretilip tüketilmesine tüm kademelerin birer veri toplayıcı aşama haline gelmektedir. 
Tablo 1. Gözetim Çeşitlerinin Turizm Endüstrisi Açısından Değerlendirilmesi

\begin{tabular}{|c|c|c|}
\hline Gözetim Türü & & Turizm Endüstrisi Çıktıları \\
\hline \multirow{3}{*}{ Veri Gözetimi } & Elde Edilişi & $\begin{array}{l}\text { - İnternet üzerinden yapılan işlemler, kredi kartı vb. elektronik yönü olan alışveriş işlemleri, } \\
\text { otomasyon sistemlerine kayıt edilen veriler, vize ve pasaport işlemleri, sosyal paylaşım siteleri, } \\
\text { gps üzerinden yer bildirimleri }\end{array}$ \\
\hline & Artılar & $\begin{array}{l}\text { - Turizm olayına katılma sürecinde kişiye uygun tercihlerin sunulması açısından karar vermede } \\
\text { kolaylık sağlar, } \\
\text { - Ulaşım vs. amaçlı bilet kesimleri veya internet üzerinden yapılan rezervasyonlarda kolay bilgi } \\
\text { ulaşımı işlem süresini düşürüp, işlemleri daha pratik hale getirir } \\
\text { - Tatil amaçlı kredi kullanımlarında daha kısa sürede banka işleminin sonlanmasına sebep olur }\end{array}$ \\
\hline & Eksiler & $\begin{array}{l}\text { - Bireysel bilgilerin ve tercihlerin istemsiz olarak toplanması } \\
\text { - Özel yaşam mahremiyetinin hiçe sayılması } \\
\text { - Toplanan verilerin internet korsanlarınca çalınması tehlikesi } \\
\text { - Toplanan verilerin hangi işletme veya ülkeler ile paylaşıldığının bilinmemesi } \\
\text { - Kişisel verilerin istem dışı herhangi bir araştırma donesi olarak kullanılabilmesi }\end{array}$ \\
\hline
\end{tabular}

Elde Edilişi

- Sit alanlarında, turistik merkezlerde ve işletmelerde kullanılan 24 saat çalışan güvenlik kameraları,

- Sürekli kamera kaydı ve gözetimi ile turistik alanlarda yaşanan suç olaylarına anında müdahale imkânı,

Fiziksel Gözetim Artılar

- Tarihi eserlerin ve kültürel mirasın daha etkin korunması, tarihi eser kaçakçılığı için güçlü bir koruma sunmas 1

- Suçlular ile mücadelede etkili bir yöntem olmas1

- Turistik işletmelerinde güvenliği sağlaması

Eksiler - Sürekli gözetimin insanları olumsuz etkilemesi

- Özel hayat mahremiyeti

Elde Edilişisi

- Rekreatif özelliği bulunan siteler veya sosyal paylaşım ağlarında ya da tatil-seyahat sitelerinde işlemler öncesi sunulan zorunlu anketler,

\begin{tabular}{|c|c|c|}
\hline Psikolojik Gözetim & Artılar & $\begin{array}{l}\text { - İşletmeler açısından, talep üzerinde uzun vadede esnekliği sağlayacak çıktılar sunabilmesi } \\
\text { - Mevcut eğilimlerle beraber müşteri beklentilerinden hareketle eksikliklerin tespiti }\end{array}$ \\
\hline & Eksiler & $\begin{array}{l}\text { - Neden doldurulduğu bilinmeyen anketlerin etik olup olmaması sorunu } \\
\text { - Anket sonuçlarının algı üzerindeki olası etkisi ile insanları belirli işletme ve destinasyonlara } \\
\text { yönlendirme çabası }\end{array}$ \\
\hline
\end{tabular}

Kaynak: Westin'in (1970) gözetim toplumu kategorilerinden yararlanılarak turizm endüstrisine uyarlanmıştır.

\section{Sonuç}

Turizm endüstrisi merkezli gelişmeleri ve akademik araştırmaları dikkate aldığımızda teknolojinin turizmin alt sektörleri içerisindeki konumunun her geçen gün daha da artacağı gözlenmektedir. Kas gücünün yerini alan makineleşme zaman içerisinde hizmet sektöründe de gittikçe daha etkin bir şekilde varlığını sürdürecektir. Bunun bir getirisi olarak da hizmeti satın alan bireylere dair depolanan bilginin içeriği ve kapsamı ile güvenlik amacı ile yapılan gözetimin kapsamı artacaktır. $\mathrm{Bu}$ sebeple işletmelerin gözetim kavramına dair benimseyecekleri politikaları amaca yönelik bir hassaslıkta seçmeleri yerinde olacaktır. Zira verileri depolama ve gözetim işlemleri yönetim ilkeleri önemsenmeksizin politikadan yoksun bir şekilde rastgele yapılması gereksiz bir maliyet unsurunu ortaya çıkaracağ gibi sistematik olmayan veri deposu amaca hizmet etmeyecek veya gerekli güvenlik hizmetini sağlayıcısına sunamayacaktır. Öte yandan amacını aşan yoğunlukta bir gözetim ve güvenlik hissi turisti rahatsı edecektir.

Yapılan bu çalışma neticesinde, gözetim toplumu ve turizm endüstrisinin birbirini beslemekte olduğu gözlenmiştir.
$\mathrm{Bu}$ ilişki kapsamında, turizm endüstrisinden gözetim dinamiklerine veri sağlanırken, gözetim aracılı̆̆ turizm de güvenlik ve sürdürülebilirliğe ilişkin önlemler alınabilmektedir. Böylece turist davranışlar ve istekleri tahmin edilebilmekte veya turistlere yol gösterilebilmektedir. $\mathrm{Bu}$ ikili ilişkiye dair sorgulanması gereken nokta, sağlanan verinin boyutu ve toplanan bilgilerin turizm endüstrisi dişında hangi alanlara ve birimlere paylaşıldığı, toplanan verilerin saklı tutulmasına ilişkin güvenliğin ise ne ölçüde olduğu ya da gelecekte ne ölçüde olacağıdır.

Bu bağlamda gözetim toplumu mantığının turizm endüstrisi tarafından nasıl kullanılacağı yönetim fonksiyonları açısından da önem taşır. Çünkü teknoloji kullanımının artacağ1 endüstride buna uygun veri işlenmesi gerekliliği de ortaya çıkmaktadır. Zira bu şekilde müşterilerden toplanan bilgiler, olması gerektiği gibi depolanarak kültürel, tarihi ve doğal mirasın korunması daha efektif kılacaktır.

Bilindiği üzere yönetimin temel fonksiyonları planlama, örgütleme, yöneltme, koordinasyon ve denetim olmak üzere beş kısımdan oluşmaktadır Yönetim fonksiyonları üzerinden 
turizm endüstrisinde gözetim kavramını şu şekilde yorumlamamız mümkündür;

Gözetimin Planlanması: Gözetimin planlanması aşaması veri gözetimi, fiziksel gözetim ve psikolojik gözetim açısından ayrı ayrı şu şekilde değerlendirilmiştir:

(i) Veri Gözetimi: Toplanılacak bilgi veya gözetimin yönünün ne olacağına karar verilmesi sürecini kapsamaktadır. İşletmenin hedef kitlesi nedir, hangi bilgilere ihtiyaç duyulmaktadır, bilgi kaynağı ne olacaktır?

(ii) Fiziksel Gözetim: Turistin ya da tarihi eserlerin güvenliği sağlamak adına turistik bölgede veya sit alanında gözetim yapılacak yerin seçilmesi, gözetlemenin nerelerden hangi kapsamda yapılacağının karar verilmesi, kamera gözetiminin boyutu (termal, normal), günün hangi sürelerinde ne yoğunlukta yapılacağı sorularına cevaplar aranır.

(iii) Psikolojik Gözetim: İşletmenin hedef kitlesinin aktif olarak kullandığ siteler veya ağlar aracılığı ile hangi soruların yöneltileceği, neyin ölçüleceği, konularına karar verilir.

Gözetimin Örgütlenmesi: Aktif olarak gözetimi yapacak birimlerin ve teknolojilerin bir araya getirilmesi sürecidir. Yapılacak gözetim bilgiye ve veriye dayalı, ayrıca psikolojik gözetim unsurlarını da içermekteyse, gerekli internet teknolojisini yönlendirecek ve toplanan verilerin analizini yapacak iş gücünün sağlanması gerekmektedir. Yapılan gözetim fiziksel ve güvenlik merkezli ise öncelikli olarak kamera teknolojisini yönlendirecek iş gücünün sağlanması, devamında ise çıkabilecek sorunlara müdahale edecek ekibin oluşturulmasını kapsar. Burada özel güvenlik güçlerinin örgütlenmesinden suç unsurunun devletin güvenlik güçlerine teslimine kadarki sürecin planlaması da yapılması gerekmektedir.

Gözetimin Yöneltilmesi: Gözetleme işlemini yapacak birimler arasındaki işbirliği ve ekip çalışmasının belirlendiği süreçte, birimler arası veri aktarımının nasıl olacağının, hangi bilgilerin yapılacak kategorilendirme çalışmalarına göre nasıl işleneceğinin belirlendiği aşamadır.

Gözetimin Koordinasyonu: İşlerin birbirini tamamlar şekilde koordineli olarak devam ettiği bu süreçte her gözetim birimi diğer birimlerde toplanan verilerin içeriğinden haberdardır. Böylece gereksiz ve fazla veri toplanılmasının önüne geçilmiş olunur. Doğru noktalarda doğru bilgilerin kaydı alınır.

Gözetimin Denetimi: Planlanana amaçlar doğrultusunda elde edilen verilerin analizini gerçekleştirerek, toplanan verilerin amaca olan hizmetinin gözden geçirildiği bölümdür. İşletme müşteri memnuniyeti için gerekli bilgileri toplayabilmiş veya bunları müşterileri memnun etmek adına kullanabilmiş midir? Diğer yandan yapılan gözetim kültürel mirasın korunmasında etkin rol oynamış mıdır, gözetim yapılan destinasyonda suç oranlarında azalma gözlenmiş midir gibi sonuç odaklı son aşamadır.

Gözetimin, yönetim fonksiyonları kapsamında yukarıdaki gibi aşamalar halinde uygulanması işletmeye hem doğru bilgileri gözetleme imkânı tanıyacak, hem sürdürülebilir politikalara yarar sağlayacak hem de işletme ve sit alanlarındaki güvenlikli ortamın oluşmasına katk1 sunacaktır. Gözetimin bu yönü dışında toplanan bilgileri farklı amaçlar için kullanmak veya işletmeye gelir getirmesi için başka kurumlarla paylaşılması, başta fark edilmesi ile büyük bir imaj kaybına sebep olacağı gibi fark edilmese bile etik olmayan bir durumu ortaya çıkartacaktır.

Yapılmış olan bu çalışma turizm endüstrisinde kendisini giderek daha da fazla hissettiren teknolojik gelişmeler ve yenilik kapsamında ortaya her geçen gün daha fazla çıkan gözetim faktörünün almış olduğu boyutu ve endüstri içerisindeki alt sektörlerde nasıl kullanıldığına dikkat çekilmiştir. $\mathrm{Bu}$ çalışmanın devamında araştırmacılar, gözetim faktörünün artmasının turistler üzerindeki etkilerini inceleyen ampirik bir çalışma yapabilirler. Aynı şekilde turizmin geliştiği bölgelerde artan gözetimin ve güvenlik önlemlerinin artışının yerel halk üzerindeki etkileri ve zaman içerisinde bu durumun gündelik hayata dair çıktıları bir başka araştırmanın konusu olabilir.

\section{Kaynakça}

Ahipaşaoğlu, S. \& Kaya, İ. (2005). Turizm Endüstrisinde Kullanılan Bilgi İletişim Teknolojileri. İrfan Arıkan (Ed.). Turizm ve Coğrafi Bilgi Sistemleri içinde (s.2648). Ankara: Gazi Kitabevi.

Bauman, Z. (1987). Legislators And Interpreters. England: Polity Press.

Busines Insider (2017). A Japanese hotel run almost entirely by robots is expanding to 100 locations. (Erişim: 22.10.2017), http://www.businessinsider.com/japansweird-hotel-run-almost-entirely-by-robots-insists-its-not -just-a-gimmick-2015-7

Değirmencioğlu, Ö., \& Ahipaşaoğlu, S. (2008). Anadolu'da Turizm Rehberliği. Ankara: Gazi Kitabevi.

Dolgun, U. (2004). Gözetim Toplumunun Yükselişi: Enformasyon Toplumundan Gözetim Toplumuna. Yönetim Bilimleri Dergisi, 1(3), 1-21.

Dolgun, U. (2008). Şeffaf Hapishane Gözetim Toplumu. İstanbul: Ötüken Yayınevi.

Fujii, E. T., \& Mak, J. (1980). Tourism and crime: Implications for regional development policy. Regional Studies, 14(1), 27-36.

Giddens, A. (1985). The Nation State and Violence. England: Polity Press.

Goeldner, C., \& Ritchie, R. (2009). Tourism: Principles, Practices, Philosophies. Canada: Wiley.

Güven, S. K. (2007). Gözetim Toplumu ve Toplumsal Meşruiyet. Doktora Tezi. İstanbul: Mimar Sinan Güzel Sanatlar Üniversitesi.

Holocomb, J., \& Pizam, A. (2006). Do Incidents of Theft at Tourist Destinations Have a Negative Effect on Tourists Decisions to Travel to Affected Destinations? Yoel Mansfeld, Abraham Pizam (Ed.). Tourism Security and Safety içinde (s.105-124), New York: Elsevier, 
İstanbullu Dinçer, F. (1999). Güneydoğu Anadolu Projesi'nde (GAP) Turizmin Çeşitlendirilmesi. Anatolia Turizm Araştırmaları Dergisi, 10, 18-30.

Ketizmen, M. (2008). Türk Ceza Hukukunda Bilişim Suçları. Ankara: Adalet Yayınları

Linda, C. M., \& Linda I.Y. (1986). Visitors as Victims: Crimes Against Tourists in Hawaii. Annals of Tourism Research, 13, 167-191.

Lyon, D. (2002). Everyday Surveillance: Personal Data And Social Classification, Information. Communication \& Society, 5, 242-257.

Marx, G. T. (2002). What's New About the "New Surveillance"? Classifying for Change and Continuity. Surveillance \& Society, 1(1), 9-29.

Mattelart, A. (2012). Gözetimin Küreselleşmesi, Güvenlileştirme Düzeninin Kökeni. Onur Gayretli \& Su Elif Karacan (Çev.). İstanbul: Kalkedon Kitap Evi.

Mühim, A. (2012). Şirket Birleşmeleri (Mergers) ve Havayolu Şirketlerinde Merger Uygulamalarina Örnekler. Yüksek Lisans Tezi. İstanbul: İstanbul Kültür Üniversitesi.

Nytimes (2014). 'Beep,' Says the Bellhop. (Erişim: 22.10.2017), http://www.nytimes.com/2014/08/12/ technology/hotel-to-begin-testing-botlr-a-roboticbellhop.html?_r=0,

Prashyanusorn, V., Kaviya, S., \& Yupapin, P. (2010). Surveillance System for SustainableTourism With Safety and Privacy Protection. Social and Behavioural Sciences, 2, 74-78.

Roney, S. A. (2002). Fordizmden Post Fordizme Geçiş Sürecinin Turizme Yansimaları: Kitle Turizmi ve Alternatif Turizm. Anatolia: Turizm Araştırmaları Dergisi, 13(1), 9-14.

Ryan, C. (1993). Crime, Violence, Terrorism and Tourism: An Accidental or Intrinsic Relationship?. Tourism Management, 14(3), 173-183

Tribe, J. (2010). The Economics of Recreation Leisure and Tourism. Spain: Elsevier.

TDK (2017). Büyük Türkçe Sözlük. Ankara: Türk Dil Kurumu. (Erişim: 10.02. 2017), tdk.gov.tr

Unwto (2017). Tourism Highlights 2017 Edition. (Erişim 22.10.2017), https://www.e-unwto.org/doi/pdf/10. $18111 / 9789284419029$

Visualise (2015). Thomas Cook Virtual Reality Holiday 'Try Before You Fly'. (Erişim: 31.01.2018), http://visualise.com/case-study/thomas-cook-virtualholiday

Walker, R., \& Walker, T. (2011). Tourism: Concepts and Practices. England: Pearson.

Weaver, A. (2008). When Tourist Become Data, Consumption, Surveillance and Commerce. Current Issues in Tourism, 11(1), 1-23.

Westin, A. (1970). Privacy and Freedom. New York: The Bodley Head. 